\title{
Морфологічні особливості та показники кислотного гемолізу еритроцитів алкоголізованих щурів за дії таурину
}

\section{Тетяна Король, Марія Вивірка}

Львівський національний університет імені Івана Франка, Львів, Україна

Адреса для листування: tetiana.korol10@gmail.com

Отримано: 03.02.19; прийнято до друку: 05.03.19; опубліковано: 28.06.19

Резюме. Споживання людиною тауриновмісних енергетичних напоїв разом з алкоголем призводить до важких функціональних розладів в організмі та навіть смерті. Зручним об'єктом для з'ясування впливу хімічних речовин на клітинні мембрани є еритроцити, а критерієм для оцінки стану клітинних мембран за дії різних чинників - показники гемолізу еритроцитів. Дослідження параметрів гемолізу проводили на суспензії еритроцитів білих щурів-самців через 2 години після одноразового внутрішньошлункового введення тваринам 40 \% етанолу або води в контролі (4 г на 1 кг маси тіла). Суспензію клітин інкубували впродовж 30 хв за температури $37^{\circ} \mathrm{C}$ у безтауриновому та тауриновмісному $(0,45$ мM) середовищах. 3'ясували, що інтенсивність гемолізу еритроцитів залежить від впливу етанолу й наявності таурину в середовищі інкубування. Спостерігали збільшення часу гемолізу 50 \% еритроцитів щурів контрольної та дослідної груп у 1,20 (p<0,01, n=4) i 1,38 (p<0,01, n=4) раза відповідно внаслідок їх інкубування в тауриновмісному середовищі. Проте за дії таурину час повного гемолізу еритроцитів алкоголізованих щурів у 1,27 раза $(\mathrm{p}<0,05, \mathrm{n}=4)$ був меншим, ніж час гемолізу еритроцитів контрольної групи тварин. Розподіл еритроцитів на групи за стійкістю до $\mathrm{HCl}$ засвідчив, що в крові алкоголізованих щурів було найбільше низькостійких і найменше середньостійких еритроцитів. Найбільший відсоток еритроцитів із підвищеною стійкістю до $\mathrm{HCl}$ ми спостерігали внаслідок дії таурину на еритроцити інтактних щурів, проте взагалі не виявили їх за впливу таурину на еритроцити алкоголізованих тварин. Також ми спостерігали агрегацію еритроцитів алкоголізованих щурів (без впливу таурину й після їх модифікації таурином) на мікрофотографіях клітин, одержаних за допомогою методів світлової та електронної мікроскопії.

Ключові слова: таурин, етанол, гемоліз еритроцитів, кислотна резистентність еритроцитів.

\section{Morphological Features and Parameters of Acid Hemolysis Alcoholized Rats' Erythrocytes Under the Action of Taurine}

\section{Tetiana Korol, Mariya Vyvirka}

Lviv National University of Ivan Franko, Lviv, Ukraine

Correspondence: tetiana.korol10@gmail.com

\begin{abstract}
Human consumption of taurine-containing energy drinks along with alcohol leads to severe functional disorders and even death. Erythrocytes are a convenient object for investigation the influence of chemicals on the cell membrane and a criterion for assessing the state of cell membranes under the action of various factors - parameters of acid hemolysis of red blood cells. The study was performed on a red blood cell suspension of white male rats in 2 hours after a single intragastric exposure of $40 \%$ ethanol or water in control ( $4 \mathrm{~g}$ per $1 \mathrm{~kg}$ of body weight). The cell suspension was incubated for $30 \mathrm{~min}$ at $37{ }^{\circ} \mathrm{C}$ in the non-taurine and taurine-containing $(0,45 \mathrm{mM})$ medium. It was found that the intensity of erythrocytes hemolysis depends on the influence of ethanol and the presence of taurine in the incubation medium. The hemolysis time of $50 \%$ of erythrocytes was increased in 1,20-fold ( $\mathrm{p}<0,01, \mathrm{n}=4)$ and 1,38 -fold $(\mathrm{p}<0,01, \mathrm{n}=4)$ in the control and experimental groups of rats respectively in response to their incubation in the taurine-containing medium. However, during the action of taurine, the time of total hemolysis of alcoholized rats' erythrocytes was decreased in 1,27-fold ( $\mathrm{p}<0,05, \mathrm{n}=4$ ) compared to the control. The distribution of erythrocytes in groups for
\end{abstract}


resistance to $\mathrm{HCl}$ showed the largest number of low resistant and the smallest number of moderately resistant cells in the blood of alcoholized rats. The highest percentage of erythrocytes with increased resistance to $\mathrm{HCl}$ was observed under the action of taurine on erythrocytes of intact rats. We did not reveal any high- $\mathrm{HCl}$ resistant erythrocytes in blood sample of alcoholized rats after incubation in taurine-containing medium. We also observed aggregation of alcoholized rats' erythrocytes (without the influence of taurine and after their modification by taurine) on micrographs of cells obtained by light and electron microscopy.

Key words : taurine, ethanol, erythrocyte hemolysis, acid resistance of erythrocytes.

\section{Вступ}

Таурин, непротеїногенна сульфуровмісна амінокислота, має низку позитивних ефектів в організмі людини i тварин: мембраностабілізаційний, антиоксидантний, антиатерогенний, ретино-, кардіо-, гепатопротекторний тощо. Це зумовило його використання в клінічній практиці. Проте застосування таурину в медицині тривалий час обмежувалося лише офтальмологією. Упродовж останніх років активно досліджують вплив таурину, напоїв або дієтичних додатків із його вмістом на морфофункціональні показники організму пацієнтів із різними захворюваннями, зокрема пригнічення надмірного росту бактерій у тонкому кишечнику [1], на стан організму онкохворих у складі ентерального харчування [2], а також на показники уваги та пам'яті практично здорових осіб [3] тощо. Водночас на сьогодні використання таурину у формі лікарських препаратів $\epsilon$ недостатнім, оскільки все ще залишаються не до кінця 3'ясованими механізми його фізіологічних ефектів на клітинному рівні.

Таурин також застосовують і в харчовій промисловості. Він, зокрема, $\epsilon$ компонентом енергетичних напоїв, які стимулюють центральну нервову систему людини та підвищують працездатність. Споживання тауриновмісних енергетичних напоїв разом 3 алкоголем призводить до важких функціональних розладів в організмі й навіть смерті. Летальні випадки від одночасного вживання етилового алкоголю та таурину спостерігали в експерименті на тваринах [4]. Вважають, що одним із можливих механізмів порушення життєдіяльності організму за цих умов $є$ гіпоглікемічний ефект. Наприклад, при одночасному введенні етанолу й таурину білим мишам спостерігали летальні випадки на тлі значного зниження рівня глюкози в плазмі крові тварин. 3'ясовано також, що несприятливий ефект комбінованої токсичної дії таурину та етанолу залежить від віку білих мишей [4]. Проте на сьогодні механізм одночасної дії етанолу й таурину на організм людини є недостатньо вивченим, оскільки ще донедавна дослідники більшу увагу приділяли впливу етанолу та кофеїну в складі енергетичних напоїв [5] або ж порівнювали ефекти кофеїновмісних і безкофеїнових напоїв [6] на фізіологічні, біохімічні, когнітивні та інші показники. На сучасному етапі досліджень, уживання етанолу й тауриновмісних напоїв вивчають, наприклад, із метою з'ясування особливостей психомоторних реакцій під час керування автомобілем, а також ризику виникнення кровотеч у водіїв [7].

Дослідження одночасної дії етанолу та таурину на функціональні показники органів і тканин розпочато порівняно недавно, а тому одержання нових експериментальних даних дасть змогу зрозуміти механізм їх впливу та попередити негативні для організму наслідки.

Зручним об'єктом для вивчення впливу хімічних речовин на клітинні мембрани $\epsilon$ еритроцити, а критерієм для оцінки стану клітинних мембран за дії різних чинників показники гемолізу еритроцитів. Тому мета нашої роботи полягала в дослідженні впливу таурину на кислотну резистентність еритроцитів щурів і їхні морфологічні особливості за одноразового введення тваринам етанолу.

\section{Матеріали та методи досліджень}

Дослідження показників кислотного гемолізу проводили на суспензії еритроцитів крові безпородних білих щурів-самців масою 250320 г. Усі тварини отримували стандартний раціон віварію та вільний доступ до води.

Алкоголізацію щурів здійснювали через одноразове внутрішньошлункове введення $40 \%$ етанолу з розрахунку 4 г чистого спирту на 1 кг маси тіла тварини. Щурам контрольної групи вводили еквівалентну кількість води. Через 2 год тварин декапітували, а з одержаної крові готували $1 \%$ суспензію еритроцитів у $0,9 \%$ розчині $\mathrm{NaCl}$. Усі маніпуляції 3 тваринами здійснювали згідно з Міжнародною конвенцією роботи 3 тваринами та Законом України «Про захист тварин від жорстокого поводження» від 26.02.2006 p.

Суспензію еритроцитів інтактних та алкоголізованих щурів інкубували впродовж 30 хв за $\mathrm{t} 37^{\circ} \mathrm{C}$ як у безтауриновому середовищі, так і в середовищі, яке містило таурин у концентрації 
0,45 мМ. Кислотний гемоліз еритроцитів здійснювали за методом Гітельзона й Терскова (1957) із додаванням у кювету $0,1 \mathrm{H} \mathrm{HCl}$. Кінетику гемолізу еритроцитів реєстрували за допомогою фотоелектроколориметра КФК-3 при довжині хвилі 650 нм через кожні 30 с.

На підставі одержаних даних побудували еритрограми та проаналізували час повного (тотального) гемолізу еритроцитів, час максимального гемолізу еритроцитів і максимальну частку (у \%) лізованих клітин. За інтенсивністю розсіяного клітинною суспензією світла визначили також час гемолізу 50 \% еритроцитів (рис.1).

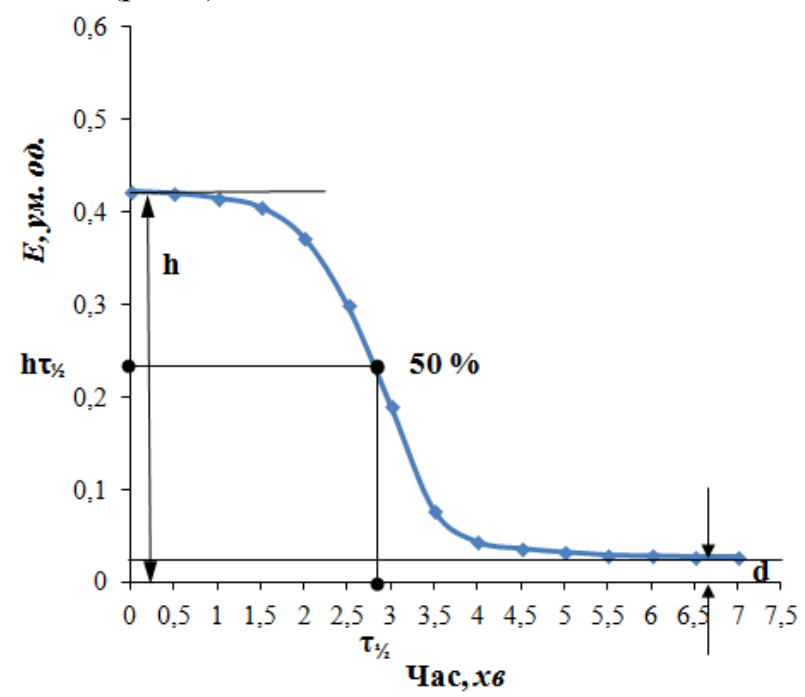

Рис. 1. Визначення часу гемолізу $50 \%$ еритройитів

$$
T=\frac{h-d}{2}+d=\frac{h-d+2 d}{2}=\frac{h+d}{2}
$$

де $h$ - величина екстинкції на початку дослідження, $d$ - величина екстинкції після завершення гемолізу. Для визначення часу гемолізу $50 \%$ еритроцитів різницю $h-d$ ділили на 2 та для повернення в початкову систему координат до одержаного результату додавали $d$. Точці $h \tau_{\frac{1}{2}}$ на осі ординат відповідає час гемолізу $50 \%$ еритроцитів $\tau_{1 / 2}$ на осі абсцис.

Для розподілу еритроцитів на групи за стійкістю до дії хлоридної кислоти криву часової залежності кількості гемолізованих еритроцитів розділили на відрізки та розрахували відсоток еритроцитів, які зазнали гемолізу в проміжок часу 0-3,0 хв; 3,5-4,5 хв; 5,0-7,0 хв відповідно. Відрізок еритрограми від 0 до 3,0 хв відображає як процес сферуляції клітин, який передує гемолізу, так і початковий етап гемолізу, під час якого руйнуються низькостійкі еритроцити та еритроцити зі зниженою стійкістю до дії кислотного гемолітика. На 3,5-4,5 хв зазнають гемолізу середньостійкі еритроцити; на 5,07,5 хв - еритроцити 3 підвищеною стійкістю та понад 7,5 хв - високостійкі еритроцити.

Інтерпретували одержані дані за допомогою порівняння показників кислотного гемолізу еритроцитів: 1) у контрольній групі щурів за наявності та відсутності таурину в середовищі інкубування; 2) у групі алкоголізованих щурів за наявності й відсутності таурину в середовищі інкубування; 3) за впливу таурину на інтенсивність гемолізу еритроцитів інтактних та алкоголізованих щурів.

Дослідження морфологічних параметрів еритроцитів крові інтактних й алкоголізованих щурів після ї інкубування в безтауриновому або тауриновмісному середовищах здійснювали 3 використанням світлового мікроскопа MICROmed XS-2610 iз фотографічною реєстрацією клітин фотокамерою Nicon D 3000. Діаметр еритроцитів визначали за допомогою програми «GIMP2».

Для дослідження ультраструктури еритроцитів їх фіксували за допомогою $1,0 \%$ розчину $\mathrm{OsO} 4$ у какодилатному буфері 90 хв при $0^{\circ} \mathrm{C}$, після чого фіксовані клітини промивали та обезводнювали в розчинах зі зростаючими концентраціями етанолу (50\%, 70 \%, 90 \% й абсолютному $100 \%$ та окису пропілену. Зразки переносили в епоксидну смолу Еpon 812. Зрізи виготовляли за допомогою ультрамікротома УМПТ-6 і контрастували цитратом свинцю за Рейнольдсом. Перегляд і фотографування зразків здійснювали на електронному трансмісійному мікроскопі ПЕМ-100 при прискорювальній напрузі 75 кВ. Вихідне збільшення на мікрофотографіях - 30000 разів. Показники збільшення на електронному мікроскопі подаються 3 точністю до $\pm 5 \%$.

Підрахунок кількості еритроцитів виконували за допомогою камери Горяєва, кров розводили, застосовуючи пробірковий метод М. Ніколаєва.

Статистично-математичне опрацювання результатів проводили з використанням пакета програм Microsoft Office Excel. Результати опрацьовували методами варіаційної статистики. Визначали достовірність змін за t-критерієм Стьюдента. Достовірною вважали різницю при $\mathrm{p}<0,05$.

\section{Результати та їх обговорення}

У дослідженні використовували кров інтактних та алкоголізованих щурів, кількість еритроцитів і вміст гемоглобіну в якій перебували в межах норми [8]. Показники крові інтактних тварин у середньому були такі: уміст 
Морфологічні особливості та показники кислотного гемолізу еритроцитів алкоголізованих щурів за дії таурину

еритроцитів - $5,82 \pm 1,6$ Т/л, концентрація гемоглобіну $-169 \pm 4,7$ г/л. Кількість еритроцитів у крові алкоголізованих щурів становила $5,56 \pm 1,2$ Т/л, а вміст гемоглобіну $-130 \pm 5,0$ г/л.

На першому етапі досліджень ми вивчали вплив таурину in vitro на показники кислотного гемолізу еритроцитів щурів. З'ясували, що час повного гемолізу еритроцитів інтактних щурів, інкубованих у безтауриновому та тауриновмісному середовищах, практично не відрізнявся й у середньому становив $5,5 \pm 0,54$ і $6,5 \pm 0,53$ хв відповідно. Час максимального гемолізу еритроцитів дорівнював $3,5 \pm 0,20$ хв та не зазнав істотних змін після їх інкубування 3 таурином $-4,0 \pm 0,23$ хв (рис. 2 ).

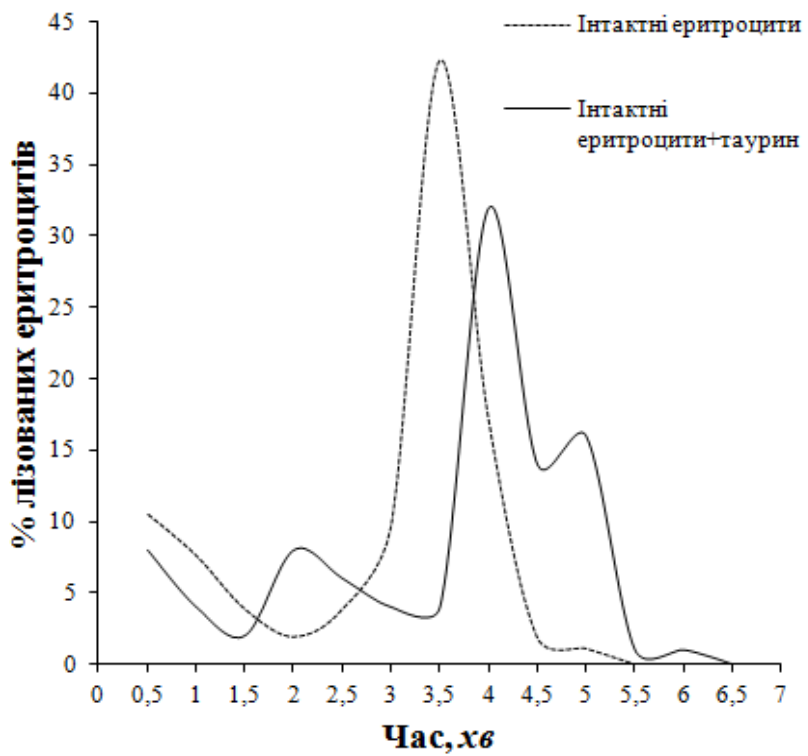

Рис. 2. Кислотні еритрограми еритроцитів інтактних шурів за діï таурину in vitro

Натомість час гемолізу $50 \%$ еритроцитів збільшився в 1,2 раза й становив $3,79 \pm 0,19$ хв $(\mathrm{p}<0,01, \mathrm{n}=4)$ після інкубування суспензії клітин у тауриновмісному середовищі. Виявлені нами зміни досліджуваного показника свідчать про стабілізаційний вплив таурину на клітинну мембрану еритроцитів щурів. Аналогічно на це вказує зменшення в 1,32 раза $(\mathrm{p}<0,01, \mathrm{n}=4)$ максимальної частки (у \%) гемолізованих еритроцитів.

На наступному етапі роботи ми дослідили показники кислотного гемолізу еритроцитів за умови короткотривалої алкоголізації щурів. Ми не виявили відмінностей у тривалості гемолізу еритроцитів після їх інкубування в безтауриновому й тауриновмісному середовищах, а одержані дані становили, відповідно, $5,5 \pm 0,52$ та $5,1 \pm 0,56$ хв (рис. 3 ).

Статистично достовірних змін зазнали показники часу гемолізу $50 \%$ еритроцитів i максимальної частки гемолізованих клітин.

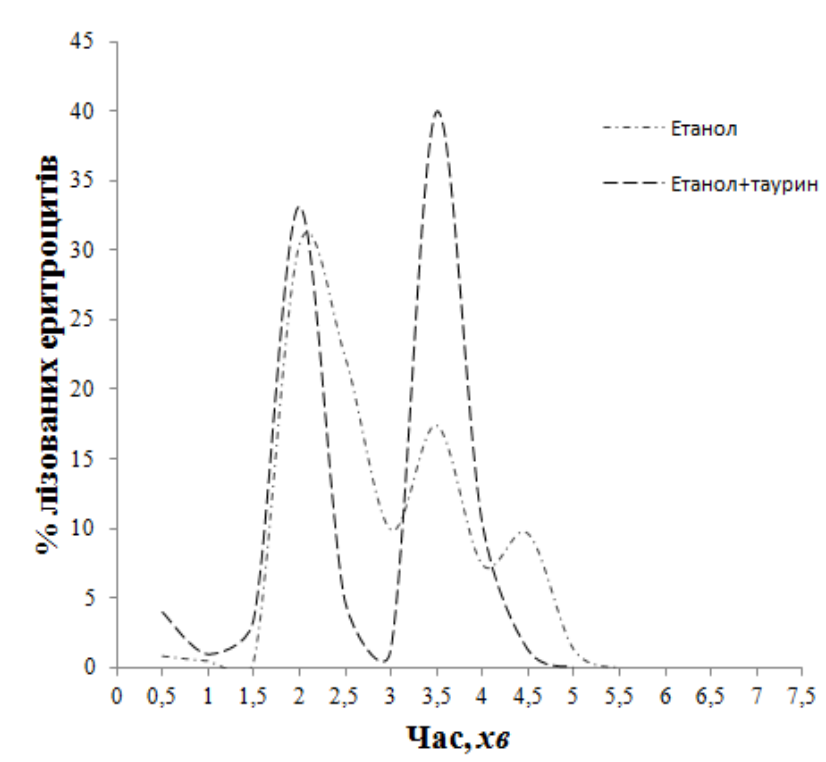

Рис. 3. Кислотні еритрограми еритрочитів алкоголізованих щурів за дї таурину in vitro

Час гемолізу 50 \% еритроцитів алкоголізованих щурів становив $2,43 \pm 0,40$ хв та збільшився в 1,38 раза $(\mathrm{p}<0,01, \mathrm{n}=4)$ після їх інкубування в тауриновмісному середовищі. Максимальна частка гемолізованих еритроцитів, як очевидно 3 рис. 3 , збільшувалася в 1,32 раза $(\mathrm{p}<0,01, \mathrm{n}=4)$ після інкубування еритроцитів із таурином у середовищі, порівняно 3 безтауриновими умовами інкубування. Це вказує на більш стрімкий, бурхливий характер гемолізу еритроцитів із максимальним піком на 3,5 хв. Натомість еритроцити алкоголізованих щурів, які не зазнали впливу таурину, гемолізували поступово, а три піки на еритрограмі, очевидно, відповідають залученню в процес руйнування старих, зрілих і молодих форм еритроцитів.

Для з'ясування особливостей впливу таурину на інтенсивність гемолізу еритроцитів інтактних та алкоголізованих щурів ми порівняли показники, одержані під час дослідження крові контрольної й дослідної груп тварин (рис. 4).

Як видно з рис. 4, за дії таурину час гемолізу еритроцитів алкоголізованих щурів у 1,27 раза $(\mathrm{p}<0,05, \mathrm{n}=4)$ був меншим, ніж час гемолізу еритроцитів контрольної групи тварин. Максимальна частка гемолізованих еритроцитів збільшилася за додавання таурину до середовища інкубування клітин крові алкоголізованих щурів в 1,25 раза $(\mathrm{p}<0,01, \mathrm{n}=4)$, порівняно 3 впливом таурину на еритроцити інтактних тварин. Ці зміни свідчать про зростання інтенсивності гемолізу еритроцитів алкоголізованих щурів за дії таурину відносно еритроцитів контрольної групи тварин, аналогічно проінкубованих у тауриновмісному середовищі. 
Науковий вісник Східноєвропейського національного університету імені Лесі Українки. Серія: Біологічні науки, 2019, 3 (387)

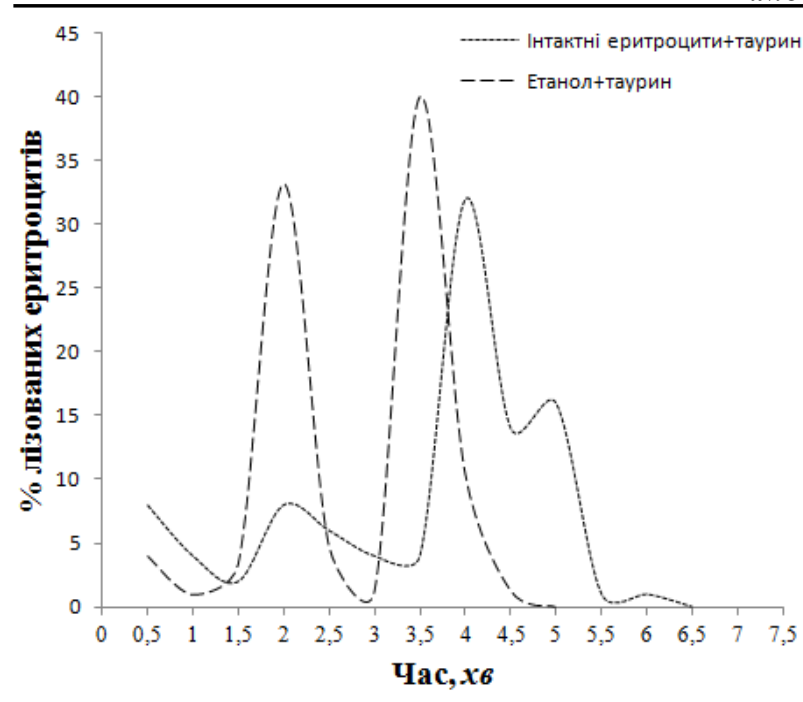

Рис. 4. Кислотні еритрограми інтактних та алкоголізованих щурів за дї таурину in vitro

Аналіз розподілу еритроцитів на групи за стійкістю до дії хлоридної кислоти свідчить, що високостійких еритроцитів, час гемолізу яких $\geq 7,5$ хв, не виявлено (табл. 1).

Найбільший відсоток низькостійких еритроцитів (час гемолізу $\leq 3,0$ хв) спостерігали під час гемолізу еритроцитів крові алкоголізованих щурів. Розрахований показник в 1,73 раза (p<0,001, $\mathrm{n}=4)$ перевищував кількість низькостійких до дії хлоридної кислоти еритроцитів крові інтактних тварин. За дії таурину відсоток низькостійких еритроцитів у крові алкоголізованих щурів зменшився в 1,40 раза $(\mathrm{p}<0,01, \mathrm{n}=4), \quad$ порівняно 3 безтауриновими умовами інкубування. Відсоток середньостійких (час гемолізу 3,54,5 хв) еритроцитів був найбільшим у крові інтактних щурів і становив $61,54 \pm 2,09 \%$. Натомість кров алкоголізованих щурів містила
34,48 $\pm 1,29 \%$ середньостійких еритроцитів, що в 1,78 раза менше $(\mathrm{p}<0,01, \mathrm{n}=4)$, ніж у крові інтактних тварин. За дії таурину в концентрації 0,45 мМ відсоток середньостійких еритроцитів збільшувався лише в крові алкоголізованих тварин. Досліджуваний показник у 1,5 раза $(\mathrm{p}<0,05, \mathrm{n}=4)$ перевищував їх кількість за відсутності таурину в середовищі інкубування й становив 51,79 $\pm 3,8$ \% від загальної кількості еритроцитів. Максимальну кількість еритро-

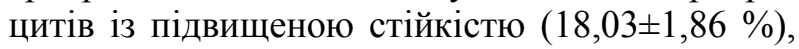
час гемолізу яких перебував у межах 5,0-7,5 хв, спостерігали за дії таурину на клітини

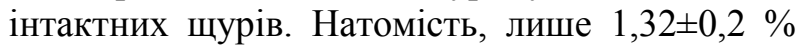
еритроцитів алкоголізованих щурів мали підвищену стійкість до дії кислотного гемолітика, проте після інкубування досліджуваних клітин крові алкоголізованих тварин у середовищі з таурином ми не виявили еритроцитів із підвищеною стійкістю.

Зменшення стійкості еритроцитів до дії кислотного гемолітика пов'язане i зі структурно-функціональними змінами клітинних мембран.

Як відомо, етанол чинить безпосередній вплив на фізико-хімічні властивості біологічних мембран клітин, зокрема еритроцитів, а саме збільшує їх флюїдизацію чи плинність. Її визначає рухомість внутрішньомембранних компонентів. Зі збільшенням плинності зменшується в'язкість матриксу мембранних ліпідів. В'язкість та структура клітинної мембрани є одними з параметрів, які визначають здатність еритроцитів до деформації. Вона, зі свого боку, забезпечує механічну стійкість еритроцитів, які циркулюють у крові, та захищає їх від фрагментації й внутрішньосудинного гемолізу.

Таблиця 1

Розподіл еритроцитів інтактних та алкоголізованих щурів на групи за стійкістю до дії кислотного гемолітика (\% лізованих еритроцитів)

\begin{tabular}{|c|c|c|c|c|c|}
\hline \multirow[b]{2}{*}{$\begin{array}{c}\text { Група } \\
\text { стійкості }\end{array}$} & \multirow[b]{2}{*}{$\begin{array}{c}\text { Інтервал } \\
\text { часу, } x в\end{array}$} & \multicolumn{4}{|c|}{ Умови досліду } \\
\hline & & $\begin{array}{c}\text { інтактні щурі, } \\
\text { о ммоль/л } \\
\text { таурину }\end{array}$ & $\begin{array}{c}\text { інтактні щурі, } \\
\text { 0,45 ммоль/л } \\
\text { таурину }\end{array}$ & $\begin{array}{c}\text { алкоголізовані } \\
\text { щурі, о ммоль/л } \\
\text { таурину }\end{array}$ & $\begin{array}{c}\text { алкоголізовані } \\
\text { щурі, 0,45 ммоль/л } \\
\text { таурину }\end{array}$ \\
\hline Низькостійкі & $0-3,0$ & $37,29 \pm 1,07$ & $32,0 \pm 2,04$ & $64,48 \pm 1,86^{* * *}$ & $47,44 \pm 3,29 * *, \# \#$ \\
\hline Середньостійкі & $3,5-4,5$ & $61,54 \pm 2,09$ & $50,0 \pm 3,99 * *$ & $34,48 \pm 1,29 * *$ & $51,79 \pm 3,80 *$,\# \\
\hline $\begin{array}{c}\text { Iз підвищеною } \\
\text { стійкістю }\end{array}$ & $5,0-7,5$ & $1,10 \pm 0,27$ & $18,03 \pm 1,86^{* *}$ & $1,32 \pm 0,2$ & - \\
\hline Високостійкі & $\geq 7,5$ & - & - & - & - \\
\hline
\end{tabular}

Примітка. *- $*_{-0,05 ;}^{* *} *_{-} p<0,01 ; * * *_{-} p<0,001$ (щуодо еритроциттів інтактних щуурів без впливу таурину) \# - $p<0,05$; \#\# - $p<0,01$ (щодо еритроцитів алкоголізованих щурів без впливу таурину). 
Морфологічні особливості та показники кислотного гемолізу еритроцитів алкоголізованих щурів за діï таурину

За гострої алкоголізації відбувається заглиблення молекул етилового спирту між полярними головками молекул фосфоліпідів, що призводить до зменшення щільності їх розміщення та збільшення плинності мембрани.

Як свідчать дані літератури, за менших концентрацій молекули спирту переважно розташовані в поверховому шарі мембрани. Подальше збільшення концентрації спирту супроводжується зануренням його молекул до гідрофобного ядра мембрани. Доведено, що етанол зменшує плинність як поверхового шару, так і гідрофобного ядра мембрани, що ініціює гемоліз еритроцитів [9] .

На еритроцитах людини, які зазнавали впливу етанолу in vitro, доведено, що етиловий спирт у концентрації $0,3 \quad \% \quad$ спричиняв статистично достовірне збільшення їх сферичності [10].

Відомо, що дестабілізаційний ефект на клітинні мембрани чинить як неметаболізований етанол, так i ацетальдегід, утворення якого в еритроциті відбувається за участю каталази. Активність еритроцитарної каталази становить близько 600 мкмоль / хв / мл крові, що відповідає перетворенню 85 ммоль етанолу до ацетальдегіду за 60 хв. У дослідженнях 3 активною та інактивованою каталазою еритроцитів продемонстровано, що за умов кислотного гемолізу дестабілізаційний ефект на клітинні мембрани чинив безпосередньо етанол, у той час як вплив ацетальдегіду виявлено за дії $\mathrm{NaOCl}$ на еритроцити [11] .

Ефекти таурину та його похідних на морфологічні особливості еритроцитів у цілому

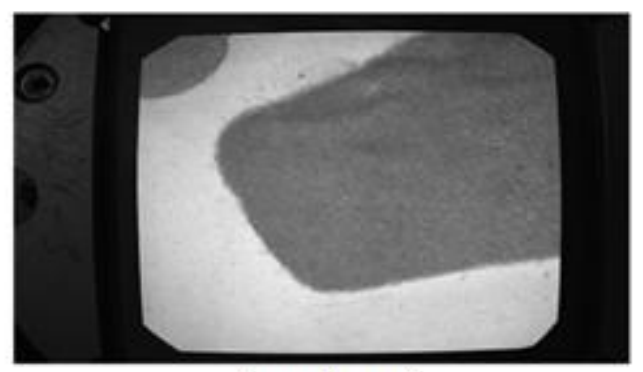

інтактні щурі

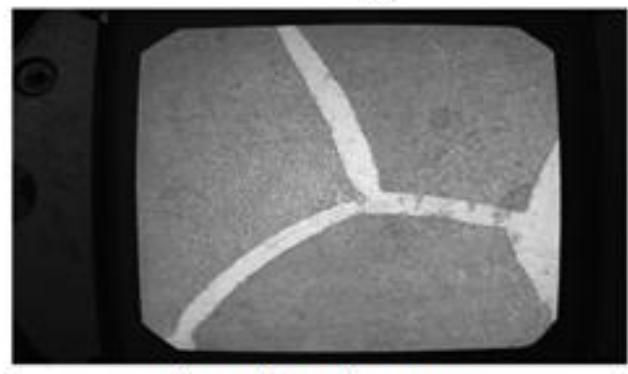

інтактні щурі + таурин й плинність клітинної мембрани та зміни структури цитоскелета зокрема більшою мірою досліджені за умов хронічної алкоголізації щурів. В експерименті гіпотаурин й гомотаурин забезпечували нормальну флюїдизацію клітинної мембрани алкоголізованих тварин, у той час як таурин не чинив істотного впливу. Таурин не змінював форму еритроцитів хронічно алкоголізованих щурів 3 ехіноцитарної до дископодібної та не забезпечував підтримання нормального розподілу білка мембранного скелета спектрину. Загалом таурин мав менш виражені протективні властивості на структуру й форму еритроцитів за умов хронічної алкоголізації тварин, ніж його аналог гіпотаурин чи гомолог амінометансульфонова кислота [12].

За дії таурину in vitro на еритроцити безпородних білих щурів-самців Огай і співавт. (2011) спостерігали збільшення тривалості періоду модифікації клітинних мембран над їх деструкцією, сповільнення переходу еритроцитів від фази сферуляції до власне гемолізу [13]. Одержані дані науковці пояснюють модифікацією таурином білкових структур еритроцитарних мембран та його здатністю відновлювати нормальний фосфоліпідний склад мембран досліджуваних клітин, а саме фізіологічне співвідношення фосфатидилетаноламіну й фосфатидилхоліну. Підтвердження цього - стабілізаційний ефект таурину в концентрації $10^{-4}$ моль/л на фосфоліпідний шар, зареєстрований на фосфоліпідних моношарових плівках. Проте вже в концентрації $10^{-3}$ моль/л таурин спричиняв його деструктивні зміни [14].

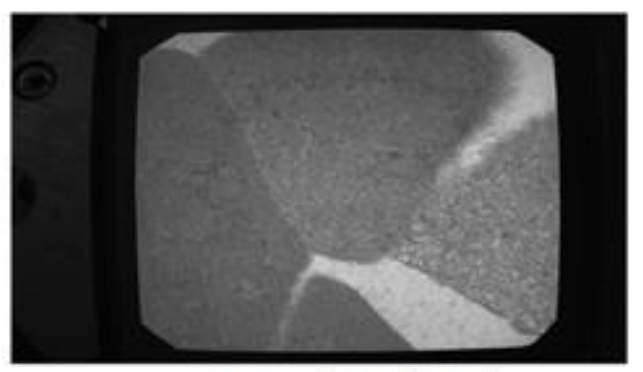

алкоголізовані щурі

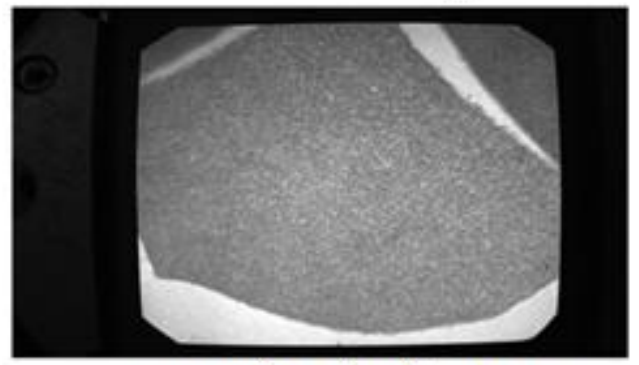

алкоголізовані шурі + таурин

Рис. 5. Мікрофотографії еритрочитів інтактних та алкоголізованих щурів (x 30 000) 
У зв'язку зі зменшенням кислотної резистентності еритроцитів за одноразового введення етанолу та дії таурину in vitro виявилося доцільним дослідити морфологічні особливості клітин за цих умов. Під час світлооптичного вивчення нативних препаратів еритроцитів щурів та 3 використанням графічного редактора GIMP2 визначили діаметр клітин усіх 4 зразків крові (Контроль; Дослід; Контроль+Таурин; Дослід+Таурин). Розраховані нами усереднені значення діаметра еритроцитів досліджуваної крові суттєво не відрізнялися між собою. Водночас ми спостерігали агрегацію клітин, а осередків скупчення клітин було більше в зразках крові алкоголізованих щурів.

Агрегацію еритроцитів алкоголізованих щурів, проінкубованих у безтауриновому та меншою мірою - у тауриновмісному середовищах, спостерігали й за допомогою методу трансмісійної електронної мікроскопії. Очевидно, ці ефекти пов'язані зі зміною поверхового заряду клітинної мембрани. У нормі еритроцити несуть від'ємний заряд і відштовхуються один від одного, що забезпечує виконання ними важливих фізіологічних функцій. Зниження негативного заряду супроводжується підвищенням здатності еритроцитів до агрегації, а відтак порушенням реологічних властивостей крові [15].

Загалом одночасний вплив етанолу й таурину на сьогодні $€$ недостатньо вивченим. Вважають, що одним із можливих механізмів порушення життєдіяльності організму за цих умов $є$ гіпоглікемічний ефект. Доведено, що мінімальні 100 \% летальні дози за комбінованого введення таурину та етанолу білим мишам залежали від їх віку й виявилися найнижчими в 7-денних тварин. У всіх вікових групах мишей летальні випадки спостерігали на тлі значного зниження рівня глюкози в плазмі крові тварин. Водночас усі миші, які отримували лише таурин або етанол, вижили [4].

\section{Висновки}

Отже, у групі алкоголізованих щурів ми спостерігали більш інтенсивний гемоліз еритроцитів за дії таурину, про що свідчить зростання часу гемолізу 50 \% клітин. Разом із тим час повного гемолізу еритроцитів не зазнав статистично достовірних змін, порівняно 3 безтауриновими умовами інкубування. Під час порівняльного аналізу часу гемолізу еритроцитів інтактних й алкоголізованих щурів, які інкубували в тауриновмісному середовищі, виявили статистично достовірне зменшення досліджуваного показника крові після одноразового введення етанолу. Розподіл еритроцитів на групи за стійкістю до дії хлоридної кислоти засвідчив, що відсоток середньостійких клітин і клітин із підвищеною стійкістю був виразно меншим у крові алкоголізованих щурів, порівняно 3 контролем. За додавання таурину до середовища інкубування еритроцитів інтактних та алкоголізованих щурів відсоток середньостійких еритроцитів в обох випадках практично не відрізнявся. Щодо еритроцитів із підвищеною стійкістю до дії кислотного гемолітика найвищий ї уміст спостерігали після інкубування еритроцитів інтактних тварин у середовищі, яке містило таурин, та взагалі не виявили за впливу таурину на еритроцити алкоголізованих тварин. Одержані результати узгоджуються 3 даними літератури, згідно 3 якими інкубування еритроцитів щурів у середовищі 3 додаванням таурину збільшувало кислотну резистентність еритроцитів загалом i час гемолізу $50 \%$ еритроцитів зокрема [13]. Проте за умов алкоголізації тварин таурин практично не нормалізував плинність плазматичної мембрани еритроцитів, їх форму та розподіл спектрину, порівняно 3 його аналогами й гомологами [12]. Щоправда, наведені дані стосуються умов хронічної алкоголізації тварин. Комбінований ефект короткотривалого введення етанолу та таурину тваринам вивчено недостатньо, що $\epsilon$ перспективою наступних етапів досліджень.

\section{Подяка}

Канд. біол. наук Кулачковському О. Р. за допомогу в проведенні електронно-мікроскопічних досліджень еритроцитів.

\section{Лiтература}

1. ClinicalTrials.gov (2018) Novel supplementbased therapy for the treatment of small intestinal bacterial overgrowth (NCT03420976), available at: https://clinicaltrials.gov/ct2/show/NCT03420976?term= taurine\&rank=40 (accessed February 2, 2018).

2. ClinicalTrials.gov (2011) Enteral nutrition in cancer patients (NCT01304446), available at : https:// clinicaltrials.gov/ct2/show/NCT01304446?term=taurine \&rank=38 (accessed February 25, 2011).

3. ClinicalTrials.gov (2016) Effects of energy drinks (NCT02727920), available at: https:// clinicaltrials.gov/ct2/show/NCT02727920?term=taurine

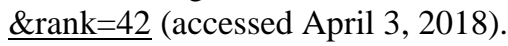

4. Taranukhin, A. G.; Saransaari, P.; Kiianmaa, K.; Oja, SS. Hypoglycemia is one possible mechanism in 
the combined toxicity of ethanol and taurine. $A d v \operatorname{Exp}$ Med Biol. Taurine-9; 2015, 803. p 305-312.

5. Wolk, B. J.; Ganetsky, M.; Babu, K. M. Toxicity of energy drinks; Curr Opin Pediatr; 2012, № 24(2), p 243-251.

6. Shah, A.; Nguyen, N.; Bhattacharyya, M. Energy implications of consuming caffeinated versus decaffeinated energy drinks. J. of Pharmacy Practice; 2015, Vol. 28(5), p 482-483.

7. ClinicalTrials.gov (2016) Interaction of alcohol with energy drinks (AEDED) (NCT02771587), available at: https://clinicaltrials.gov/ct2/show/NCT0 2771587? term $=$ taurine $\&$ draw $=3 \&$ rank $=2 \quad$ (accessed October 19, 2016).

8. Запорожан, В. М.; Напханюк, В. К.; Горянова, Н. О.; Бажора, Ю. І.; Кресюн, В. Й.; Сервецький К. Л. Морфологія клітин крові лабораторних тварин і людини: Атлас; Одеса, 2002, 118 с.

9. Sommez, M.; Ince, H. Y.; Yalcin, O. The effect of alcohols on red blood cell mechanical properties and membrane fluidity depends on their molecular size. PLOS One; 2013, № 8(9).: e76579.

10. Lee, S. Y.; Park, H. J.; Best-Popescu, C.; Jang, S.; Park, Y. K. The effects of ethanol on the morphological and biochemical properties of individual human red blood cells. PLOS One; 2015, 10 (12): e0145327.
11. Tyulina O. V.; Huentelmanbc, $\quad$ M. J.; Prokopieva, V. D.; Boldyrev, A. A; Johnson, P. Does ethanol metabolism affect erythrocyte hemolysis? BBA Molecular Basis of Disease; 2000, V.1535 (1), p 69-77.

12. Gossai, D.; Lau-Cam, C. A. The effects of taurine, hypotaurine, and taurine homologs on erythrocyte morphology, membrane fluidity and cytoskeletal spectrin alterations due to diabetes, alcoholism and diabetes-alcoholism in the rat. Adv Exp Med Biol. Taurine-7; 2009, 643; p 369-379.

13. Огай, М. А; Степанова, Э. Ф.; Холодов, Д. Б.; Николаевский, В. А. Антиоксидантный и мембраностабилизирующий эффект таурина. Вестник ВГУ. Серия «Химия. Биология. Фармаџия»; 2011, №1, c 186-191.

14. Ляхов, А. М.; Яковлєва, І. Ю.; Олійник, С. А. Особливості взаємодії ергогенних лікарських засобів таурину та яктону 3 фосфоліпідними ленгмюрівськими моношарами. Сучасні проблеми токсикологї̈; 2008, № 4, с 45-48.

15. Сфіменко, Н. В.; Сибірна, Н. О. Вплив Lаргініну та $\mathrm{N} \Omega$-нітро-L-аргінін метилового ефіру на структурно-функціональний стан мембрани еритроцитів щурів за умов алкогольної інтоксикації: Вісник Львівського університету. Серія біологічна; 2016, Вип. 73, с137-143. 